\title{
Dimethoxymethane Oxidation in a Flow Reactor
}

\author{
Lorena Marrodán, Fabiola Monge, Ángela Millera, Rafael Bilbao, and María U. Alzueta \\ Aragón Institute of Engineering Research (I3A), Department of Chemical and Environmental Engineering, \\ University of Zaragoza, Zaragoza, Spain
}

\begin{abstract}
The simultaneous reduction of $\mathrm{NO}_{\mathrm{x}}$ and soot emissions from diesel engines is a major research subject and a challenge in today's world. One prospective solution involves diesel fuel reformulation by addition of oxygenated compounds, such as dimethoxymethane (DMM). In this context, different DMM oxidation experiments have been carried out in an atmospheric pressure gas-phase installation, in the 573-1373 $\mathrm{K}$ temperature range, from pyrolysis to fuel-lean conditions. The results obtained have been interpreted by means of a detailed gas-phase chemical kinetic mechanism. Results indicate that the initial oxygen concentration slightly influences the consumption of DMM. However, certain effects can be observed in the profiles of the main products $\left(\mathrm{CH}_{4}, \mathrm{CH}_{3} \mathrm{OH}, \mathrm{CH}_{3} \mathrm{OCHO}, \mathrm{CO}\right.$, $\mathrm{CO}_{2}, \mathrm{C}_{2} \mathrm{H}_{2}, \mathrm{C}_{2} \mathrm{H}_{4}$, and $\mathrm{C}_{2} \mathrm{H}_{6}$ ). Acetylene, an important soot precursor, is only formed under pyrolysis and reducing conditions. In general, a good agreement between experimental and modeling data was observed.
\end{abstract}

\section{ARTICLE HISTORY}

Received 3 November 2015

Revised 22 June 2015

Accepted 19 November 2015

\section{KEYWORDS}

Dimethoxymethane (DMM); Flow reactor; Kinetic model; Oxidation

\section{Introduction}

In the past several years, diesel has been one of the most used fuels in transportation because of its higher fuel efficiency and lower exhaust emissions of hydrocarbons, $\mathrm{CO}$, and $\mathrm{CO}_{2}$ compared to gasoline. However, nitrogen oxides $\left(\mathrm{NO}_{\mathrm{x}}\right)$ and particulate matter, mainly soot, are the most critical pollutants produced by diesel engines, and the reduction of both simultaneously becomes one of the main obstacles in its development because of the increasing environmental protection concern and the implementation of the emission restrictions. Some measures for their minimization have been proposed, such as increasing the injection pressure, recirculation of the exhaust gas, or fuel reformulation by adding oxygenated additives. The use of these additives increases the oxygen content, producing a cleaner burning of the fuel. Furthermore, the use of oxygenates modifies as well the fuel properties, such as density, viscosity, volatility, behavior at low temperatures, and cetane number (Ribeiro et al., 2007). The changes in the properties also lead to fuel combustion modifications, which may result in a simultaneous reduction of particulate matter and $\mathrm{NO}_{\mathrm{x}}$. For this reason, some compounds, such as methanol (Chao et al., 2001), ethanol (He et al., 2003), and dimethylether (Ying et al., 2008), have been extensively studied.

Dimethoxymethane $\left(\mathrm{DMM} ; \mathrm{CH}_{3} \mathrm{OCH}_{2} \mathrm{OCH}_{3}\right)$ is a diether of interest because it is a liquid, $100 \%$ miscible in diesel fuel, does not have $\mathrm{C}-\mathrm{C}$ atomic bonds, and contains $42 \%$ 
oxygen by weight. All of these characteristics, and the decrease of the cetane number compared to conventional diesel fuels, cause a delay of the ignition time, which allows more air to be drawn into the fuel jet and reduce the production of particulate matter (Song and Litzinger, 2006).

The first study on DMM oxidation found in the literature is reported by Molera et al. (1977). Their experimental data suggest that the DMM oxidation is initiated by hydrogen abstraction reactions forming $\mathrm{CH}_{3} \mathrm{OCH}_{2} \mathrm{OCH}_{2}$ and $\mathrm{CH}_{3} \mathrm{OCHOCH}_{3}$ radicals. Daly et al. (2001) investigated the oxidation of DMM in a jet-stirred reactor at pressures of 5.07 bar, temperatures from $800 \mathrm{~K}$ to $1200 \mathrm{~K}$, and equivalence ratios of $0.444,0.889$, and 1.778 . The results obtained were interpreted by using a detailed chemical mechanism with a good agreement between experimental and calculated data. Some years later, Sinha and Thomson (2004) determined, at atmospheric pressure, the species concentrations and temperatures across opposed flow diffusion flames of three different C3 oxygenated hydrocarbons, among which DMM was considered. In addition, the results obtained were compared with those of propane-DMM blends, concluding that the presence of DMM reduces the formation of ethylene and acetylene, which are the main soot precursors. Dias et al. (2010) and Dias and Vandooren (2011) developed a reaction mechanism taking into account the formation and the consumption of oxygenated species involved in dimethoxymethane oxidation, which contained 480 reactions and 90 chemical species. Recently, Zhang et al. (2014) performed autoignition delay time measurements for dimethoxymethane/oxygen/argon mixtures at 2, 4, and $10 \mathrm{~atm}$, temperatures of 1103-1454 K, and different dilution and equivalence ratios. Their results were compared with those calculated from the previously proposed mechanism by Dias et al. (2010) with good agreement.

In this context, the present work on the DMM oxidation under well controlled tubular flow reactor conditions at atmospheric pressure represents the starting point of a deep research of this compound, which will be extended with the study of its oxidation at higher pressures (20-60 bar), and both in the presence and absence of NO. Therefore, a large number of experimental results will be available. Further, the DMM sooting tendency will be studied in its mixtures with acetylene, which is considered to be one of the main soot precursors.

\section{Experimental section}

The experiments of the dimethoxymethane oxidation have been carried out in an experimental installation successfully used by our research group and previously described in detail elsewhere (e.g., Alzueta et al., 1998); only a brief description is given here. The quartz flow reactor, built according to the design of Kristensen et al. (1996), has a reaction zone of $8.7 \mathrm{~mm}$ inside diameter and $200 \mathrm{~mm}$ in length. It is placed in a three-zone electrically heated oven ensuring a uniform temperature profile within $\pm 10 \mathrm{~K}$ throughout the reaction zone.

Gases are fed to the system through mass flow controllers, in four separate streams: one flow containing nitrogen and water vapor and three injector tubes containing dimethoxymethane, $\mathrm{O}_{2}$ and $\mathrm{N}_{2}$, respectively. Water vapor, approximately $7000 \mathrm{ppm}$, is introduced in the reactor by saturating a $\mathrm{N}_{2}$ stream through a water bubbler. $\mathrm{N}_{2}$ is used to achieve a 
Table 1. Matrix of experimental conditions.

\begin{tabular}{lcccc}
\hline Set & DMM (ppm) & $\mathrm{O}_{2}(\mathrm{ppm})$ & $\mathrm{H}_{2} \mathrm{O}(\mathrm{ppm})$ & $\lambda$ \\
\hline 1 & 653 & 0 & 6918 & 0 \\
2 & 668 & 1113 & 6466 & 0.4 \\
3 & 648 & 1946 & 6918 & 0.7 \\
4 & 626 & 2782 & 6484 & 1 \\
5 & 653 & 97,327 & 6918 & 35 \\
\hline
\end{tabular}

Note. The experiments are conducted at a constant flow rate of $1000 \mathrm{~mL}(\mathrm{STP}) / \mathrm{min}$, at atmospheric pressure, in the temperature interval of 573-1373 K. The residence time is dependent on the reaction temperature: $t_{r}(\mathrm{~s})=195 / \mathrm{T}(\mathrm{K})$. The balance is closed with $\mathrm{N}_{2}$.

total flow rate of $1000 \mathrm{~mL}(\mathrm{STP}) / \mathrm{min}$, resulting in a gas residence time dependent on the reaction temperature of $195 / \mathrm{T}(\mathrm{K})$.

A concentration of approximately $700 \mathrm{ppm}$ of DMM is introduced in all of the experiments. For a given value of the air excess ratio $(\lambda)$ defined as the inlet oxygen concentration divided by the stoichiometric oxygen, the amount of $\mathrm{O}_{2}$ is determined. This amount has been varied between 0-98,000 ppm. Each set of experiments has been carried out at atmospheric pressure covering the 573-1373 K temperature range. Table 1 summarizes the conditions of the experiments performed.

At the outlet of the reaction zone, the gas product is quenched by cooling air and before analysis it passes through a condenser and a filter to ensure gas cleaning. The outlet gas composition is analyzed by a micro-gas chromatograph equipped with TCD detectors, which detect and quantify DMM, CO, $\mathrm{CO}_{2}, \mathrm{CH}_{3} \mathrm{OCHO}, \mathrm{CH}_{3} \mathrm{OH}, \mathrm{CH}_{4}, \mathrm{C}_{2} \mathrm{H}_{2}, \mathrm{C}_{2} \mathrm{H}_{4}$, $\mathrm{C}_{2} \mathrm{H}_{6}$, and $\mathrm{H}_{2}$. The uncertainty of the measurements is estimated as $\pm 5 \%$. Carbon-balance was checked for the experiments and, in general, was found to be close within $100 \pm 10 \%$.

\section{Modeling section}

The gas-phase chemical kinetic mechanism developed in the present work was initially built from the work of Glarborg et al. (1998), which describes the interactions among C1$\mathrm{C} 2$ hydrocarbons and $\mathrm{NO}_{\mathrm{x}}$, extended and updated later by Glarborg et al. (2003) and Skjoth-Rasmussen et al. (2004). Additional reaction subsets for dimethyl ether (Alzueta et al., 1999), ethanol (Alzueta and Hernández, 2002), acetylene (Alzueta et al., 2008), and methyl formate (Marrodán et al., 2014) have been added. For the DMM oxidation, the subset proposed by Dias et al. (2010) was taken.

The resultant mechanism, developed to describe the dimethoxymethane oxidation at atmospheric pressure under a wide range of operating conditions, has been validated with the present experimental data. Thermodynamic data for the involved species were taken from the same sources as the origin mechanisms. The modeling study was performed using SENKIN, the plug flow reactor code that runs in conjunction with the Chemkin-II library (Kee et al., 1991; Lutz et al., 1988), considering constant temperature and pressure in the reaction zone, which has been tested to be a fairly good assumption.

\section{Results and discussion}

In this work, a wide study of the oxidation of dimethoxymethane has been carried out, under flow reactor conditions at atmospheric pressure in the 573-1373 K temperature 
range and for different air/fuel ratios $(\lambda=0,0.4,0.7,1$, and 35). From now on, $\lambda=0.4$ is referred to as very reducing conditions and $\lambda=0.7$ as reducing conditions. With the model validated with the present experimental results, reaction path and sensitivity analyses have been performed in order to identify the most important reactions involved in the conversion of DMM under the conditions of the present work.

Figures 1-3 show both the experimental and modeling results for the consumption of DMM, and the formation of the main products $\left(\mathrm{CO}, \mathrm{CO}_{2}, \mathrm{H}_{2}, \mathrm{CH}_{3} \mathrm{OH}, \mathrm{CH}_{3} \mathrm{OCHO}, \mathrm{CH}_{4}\right.$, $\mathrm{C}_{2} \mathrm{H}_{2}, \mathrm{C}_{2} \mathrm{H}_{4}$, and $\mathrm{C}_{2} \mathrm{H}_{6}$ ) as a function of temperature for the different air/fuel ratios. Symbols denote experimental results and lines denote modeling calculations. In general, the model is able to predict satisfactorily the main experimental trends under the present conditions.

Figure 1 shows the influence of the temperature and $\lambda$ value on the concentration of DMM and the formation of the products $\mathrm{CO}, \mathrm{CO}_{2}$, and $\mathrm{H}_{2}$. The DMM consumption occurs in the 973-1123 K temperature range. The temperature for the onset of the DMM conversion is almost independent of the stoichiometry studied, even though both experimental and theoretical results obtained under highly oxidizing conditions $(\lambda=35)$ are slightly shifted toward lower temperatures. Thus, it can be said that the oxygen concentration in the reactant mixture slightly influences the conversion of DMM, similar to what has been observed in the case of other oxygenated compounds, such as DME (Alzueta et al., 1999). Another important aspect to highlight is that DMM is consumed completely,
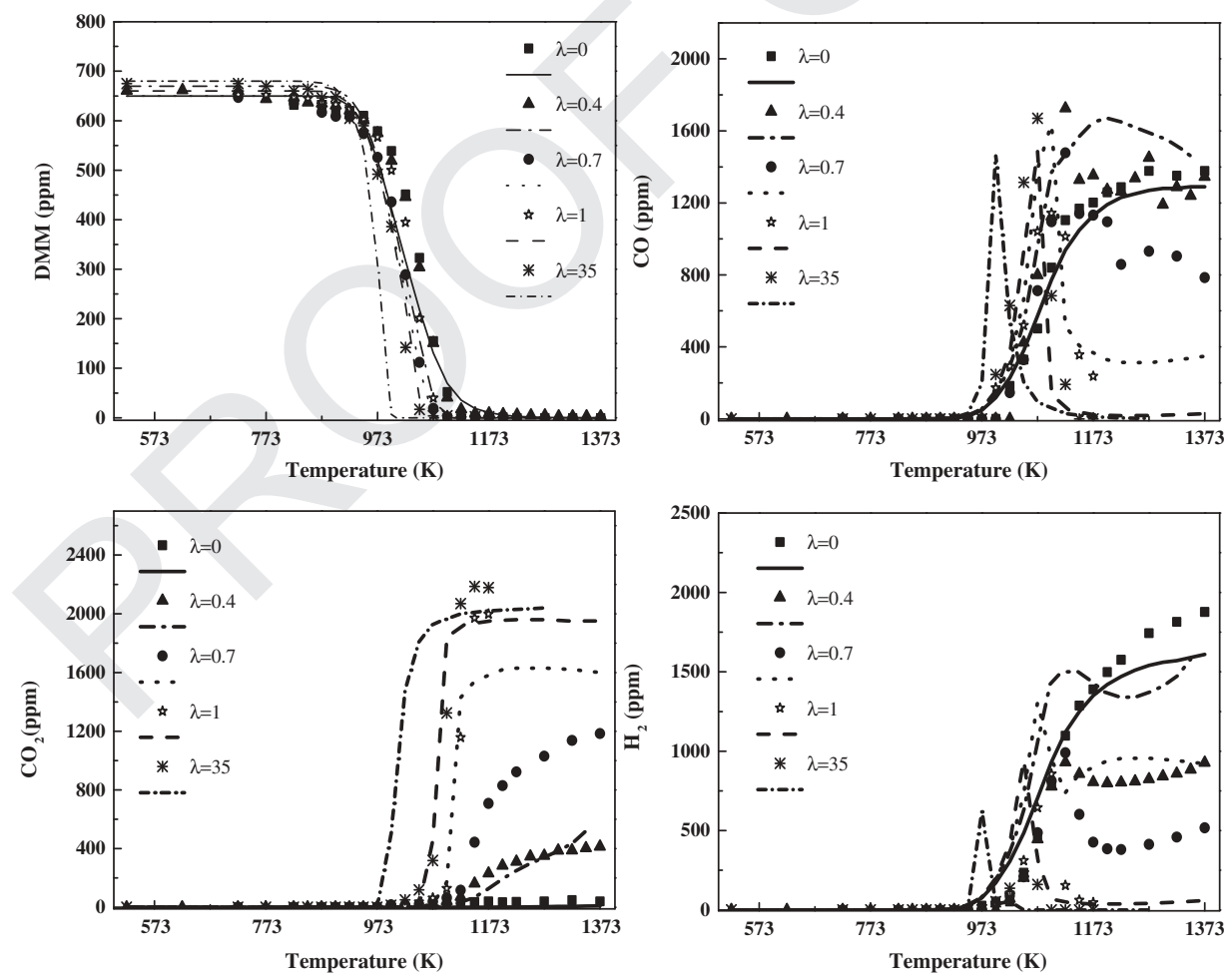

Figure 1. Influence of the air excess ratio $(\lambda)$ on the $\mathrm{DMM}, \mathrm{CO}, \mathrm{CO}_{2}$, and $\mathrm{H}_{2}$ concentration profiles as a function of the temperature. 
independently of the oxygen availability, in all of the conditions studied at temperatures above $1150 \mathrm{~K}$.

However, the presence of oxygen does have certain effects on some of the reaction products, which are described here. The onset for the formation of $\mathrm{CO}$ occurs approximately at the same temperature as the DMM starts to be consumed. When the temperature increases, the $\mathrm{CO}$ concentration increases as well, reaching a maximum value. As the air excess ratio increases, the temperature for this maximum $\mathrm{CO}$ concentration is slightly shifted towards lower temperature values, and also the width of the $\mathrm{CO}$ peak is narrower. The oxygen availability also influences the oxidation of $\mathrm{CO}$ to $\mathrm{CO}_{2}$. While under pyrolysis and very reducing conditions, $\mathrm{CO}_{2}$ is hardly formed; under reducing conditions, an appreciable amount of $\mathrm{CO}_{2}$ is produced, which coexists with a non-negligible amount of $\mathrm{CO}$; and for stoichiometric and oxidizing conditions, $\mathrm{CO}$ is completely oxidized to $\mathrm{CO}_{2}$. In the case of the $\mathrm{H}_{2}$ production, the general trend is the opposite of the $\mathrm{CO}_{2}$ case. The biggest concentration of $\mathrm{H}_{2}$ is reached for pyrolysis conditions and the lowest one for oxidizing conditions. The $\mathrm{H}_{2}$ concentration profile presents a maximum as a function of temperature; beyond that it begins to drop to zero (stoichiometric and oxidizing conditions) or to an almost constant value (reducing and very reducing conditions). The only case where $\mathrm{H}_{2}$ continues growing is in the absence of oxygen.

Figures 2 and 3 show the concentration profiles for $\mathrm{CH}_{3} \mathrm{OH}$ and $\mathrm{CH}_{3} \mathrm{OCHO}(\mathrm{MF})$, and $\mathrm{CH}_{4}, \mathrm{C}_{2} \mathrm{H}_{6}, \mathrm{C}_{2} \mathrm{H}_{4}$, and $\mathrm{C}_{2} \mathrm{H}_{2}$, respectively, as a function of the temperature. All of these compounds reach a maximum concentration, which is shifted to lower temperatures when the reactant mixture becomes fuel-leaner. In general, there is a good agreement between experimental and calculated results, with the exception of $\mathrm{MF}$ and $\mathrm{MeOH}$. As it will be discussed later, MF is an important intermediate in the DMM conversion and it produces methanol through reaction (r.1):

$$
\mathrm{CH}_{3} \mathrm{OCHO}(+\mathrm{M}) \rightleftharpoons \mathrm{CH}_{3} \mathrm{OH}+\mathrm{CO}(+\mathrm{M})
$$

There is a considerable uncertainty in the value of the activation energy for this reaction. In a previous work of our group on methyl formate oxidation at atmospheric pressure (Alzueta et al., 2013), the impact of varying the activation energy value was evaluated. Changes between 50.0 and $68.3 \mathrm{kcal} / \mathrm{mol}$ (values interval found in the literature)
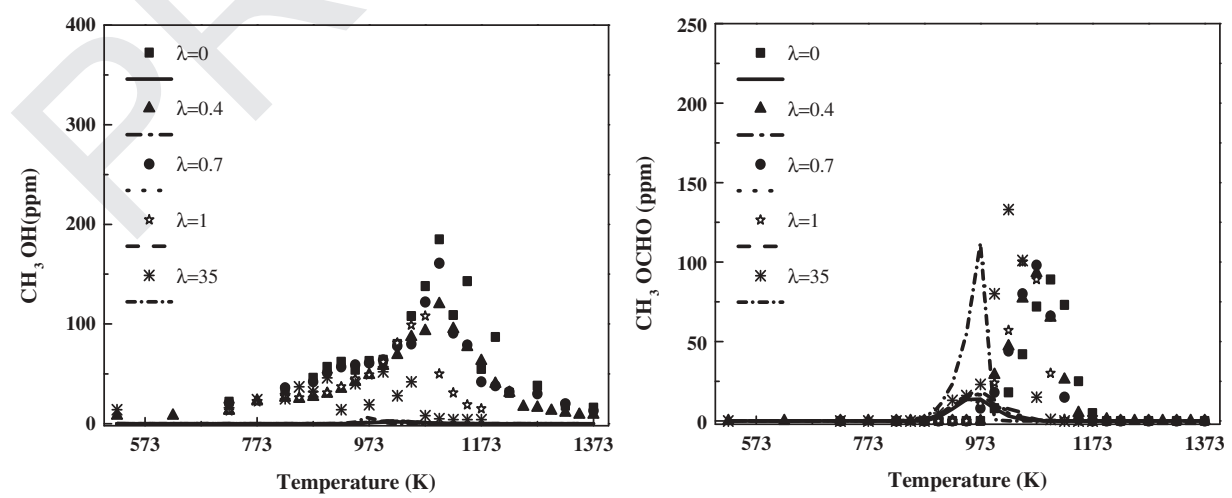

Figure 2. Influence of the air excess ratio $(\lambda)$ on the $\mathrm{CH}_{3} \mathrm{OH}$ and $\mathrm{CH}_{3} \mathrm{OCHO}$ concentration profiles as a function of the temperature. 

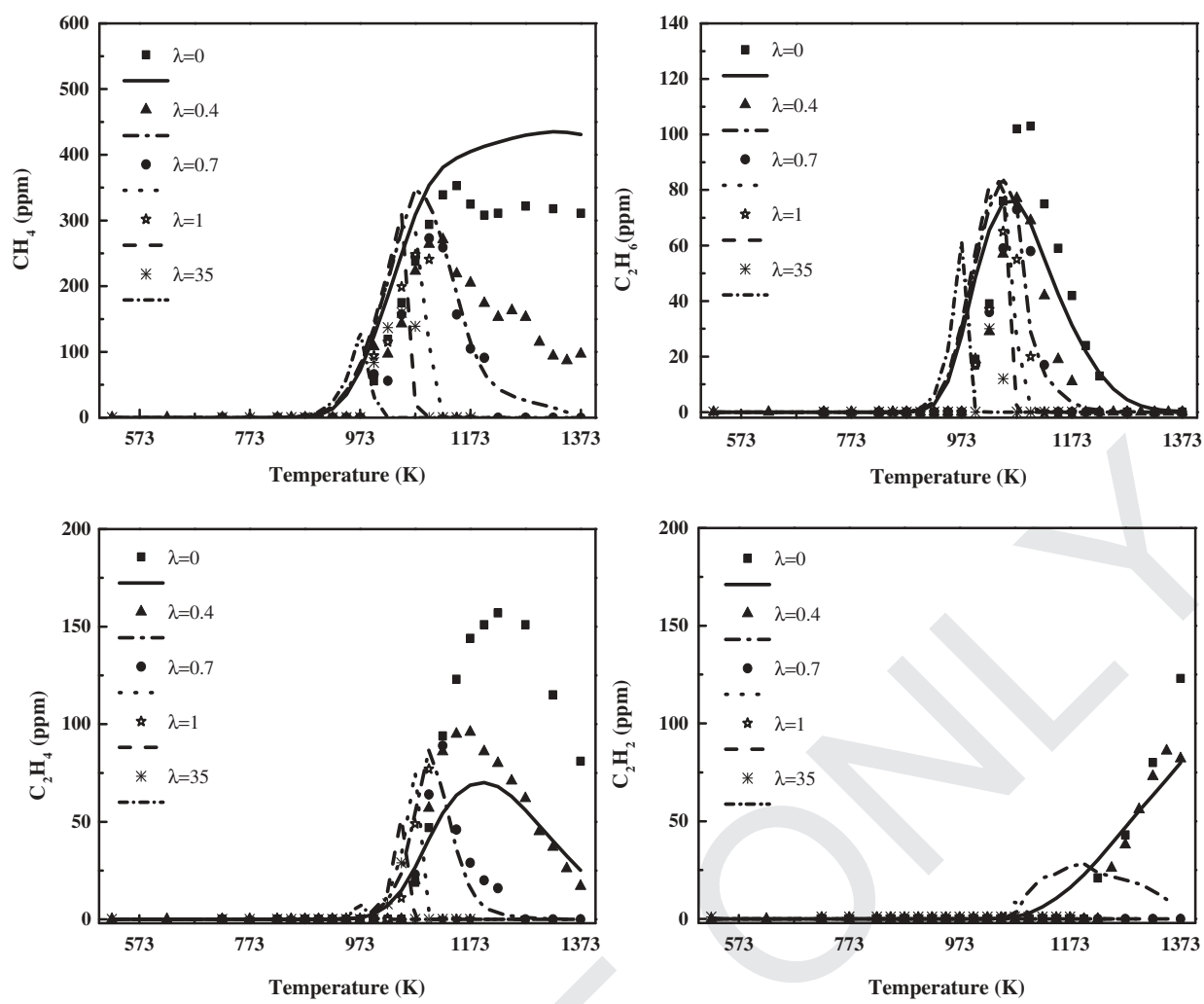

Figure 3. Influence of the air excess ratio $(\lambda)$ on the $\mathrm{CH}_{4}, \mathrm{C}_{2} \mathrm{H}_{6}, \mathrm{C}_{2} \mathrm{H}_{4}$, and $\mathrm{C}_{2} \mathrm{H}_{2}$ concentration profiles as a function of the temperature.

showed a great influence on the consumption of MF and formation of the main products. The value of $60.0 \mathrm{kcal} / \mathrm{mol}$, following Dooley et al. (2010), was finally chosen. This value has been adopted in this work, although changes in this value have a considerable impact in the $\mathrm{MF}$ and $\mathrm{MeOH}$ predictions under the conditions of this work.

It is important to note that acetylene $\left(\mathrm{C}_{2} \mathrm{H}_{2}\right)$ has only been detected under pyrolysis and very reducing conditions. For the latter ones, the model underpredicts the concentration of $\mathrm{C}_{2} \mathrm{H}_{2}$.

In order to explain the experimental concentration profiles obtained and identify the main reaction routes, a reaction rate analysis with the mechanism compiled in the present work was performed. The reaction path diagram for DMM oxidation obtained is represented in Figure 4. As an example, for stoichiometric conditions and for different temperatures, the relative importance (\%) of the two main DMM consumption steps is shown.

In most of the present conditions, the DMM conversion is initiated by the decomposition reactions (r.2) and (r.3), even though the main consumption channel of DMM is the hydrogen abstraction by different radicals $\left(\mathrm{H}, \mathrm{OH}, \mathrm{O}, \mathrm{CH}_{3}\right)$ to obtain the primary radical $\mathrm{CH}_{3} \mathrm{OCH}_{2} \mathrm{OCH}_{2}$, or the secondary radical $\mathrm{CH}_{3} \mathrm{OCHOCH}_{3}$ :

$$
\mathrm{CH}_{3} \mathrm{OCH}_{2} \mathrm{OCH}_{3}+\mathrm{M} \rightleftharpoons \mathrm{CH}_{3}+\mathrm{CH}_{3} \mathrm{OCH}_{2} \mathrm{O}+\mathrm{M}
$$




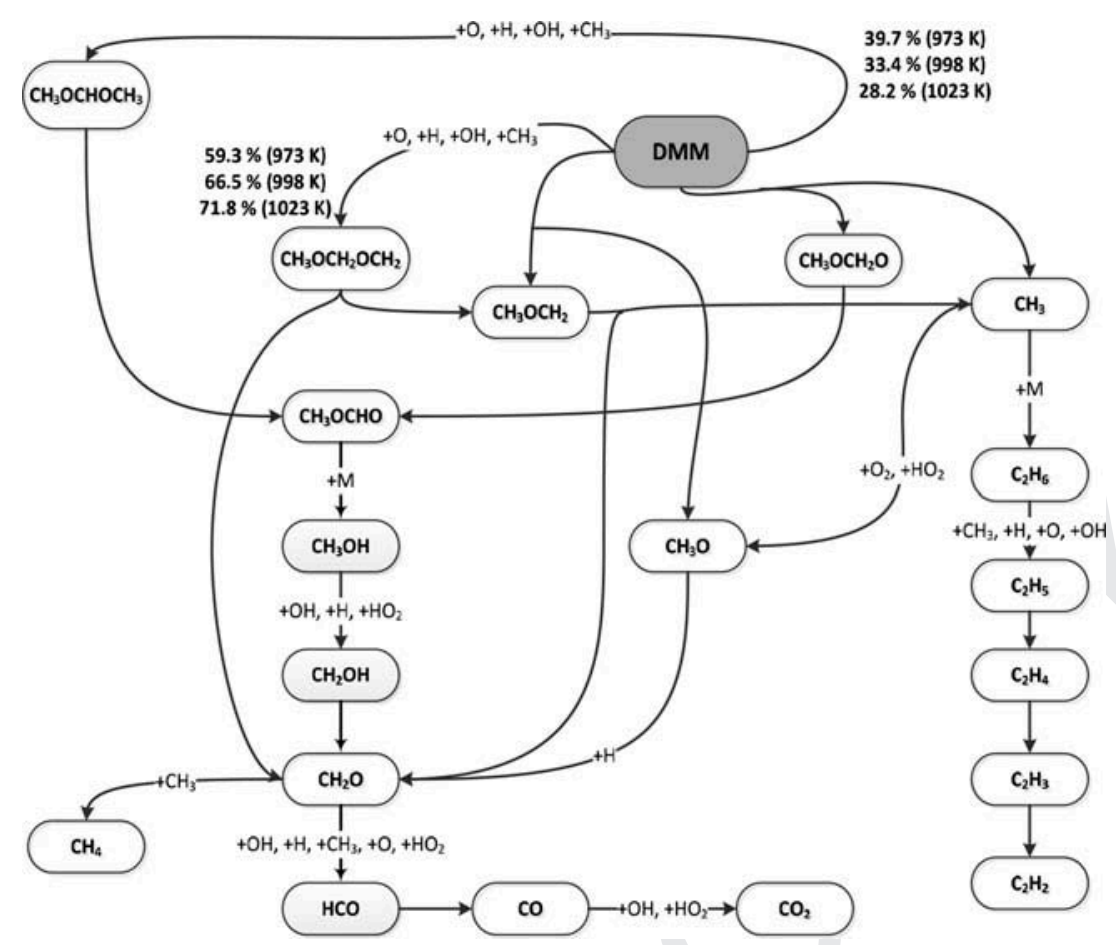

Figure 4. Reaction path diagram for DMM oxidation according to the current kinetic model.

$$
\mathrm{CH}_{3} \mathrm{OCH}_{2} \mathrm{OCH}_{3}+\mathrm{M} \rightleftharpoons \mathrm{CH}_{3} \mathrm{O}+\mathrm{CH}_{3} \mathrm{OCH}_{2}+\mathrm{M}
$$

The DMM radicals generated $\left(\mathrm{CH}_{3} \mathrm{OCH}_{2} \mathrm{OCH}_{2}\right.$ and $\left.\mathrm{CH}_{3} \mathrm{OCHOCH}_{3}\right)$ decompose through reactions (r.4) and (r.5):

$$
\begin{gathered}
\mathrm{CH}_{3} \mathrm{OCH}_{2} \mathrm{OCH}_{2} \rightleftharpoons \mathrm{CH}_{2} \mathrm{O}+\mathrm{CH}_{3} \mathrm{OCH}_{2} \\
\mathrm{CH}_{3} \mathrm{OCHOCH}_{3} \rightleftharpoons \mathrm{CH}_{3} \mathrm{OCHO}+\mathrm{CH}_{3}
\end{gathered}
$$

The $\mathrm{CH}_{3} \mathrm{OCH}_{2} \mathrm{O}$ and $\mathrm{CH}_{3} \mathrm{OCH}_{2}$ species, obtained in reaction (r.2) and reactions (r.3) and (r.4), decompose totally to $\mathrm{CH}_{3} \mathrm{OCHO}\left(\mathrm{MF}\right.$ ) [reaction (r.6)], and $\mathrm{CH}_{3}$ and $\mathrm{CH}_{2} \mathrm{O}$ [reaction (r.7)], respectively:

$$
\begin{gathered}
\mathrm{CH}_{3} \mathrm{OCH}_{2} \mathrm{O}+\mathrm{M} \rightleftharpoons \mathrm{CH}_{3} \mathrm{OCHO}+\mathrm{H}+\mathrm{M} \\
\mathrm{CH}_{3} \mathrm{OCH}_{2} \rightleftharpoons \mathrm{CH}_{3}+\mathrm{CH}_{2} \mathrm{O}
\end{gathered}
$$

The methyl formate obtained by this route or from the $\mathrm{CH}_{3} \mathrm{OCHOCH}_{3}$ thermal degradation (r.5), follows the same reaction pathways described in detail in an earlier work of our research group (Marrodán et al., 2014) and only a brief discussion is given here.

The MF oxidation is initiated by the following decomposition reaction:

$$
\mathrm{CH}_{3} \mathrm{OCHO}(+\mathrm{M}) \rightleftharpoons \mathrm{CH}_{3} \mathrm{OH}+\mathrm{CO}(+\mathrm{M})
$$

with minor relevance of reactions (r.8) and (r.9): 
Table 2. Elementary reactions and kinetic parameters for selected reactions.

\begin{tabular}{|c|c|c|c|c|}
\hline Reaction & $A$ & $n$ & $E_{a}$ & Source \\
\hline $\mathrm{CH}_{3} \mathrm{OCH}_{2} \mathrm{OCH}_{3}+\mathrm{M} \rightleftharpoons \mathrm{CH}_{3}+\mathrm{CH}_{3} \mathrm{OCH}_{2} \mathrm{O}+\mathrm{M}$ & $2.62 \mathrm{E}+16$ & 0.0 & 82,200 & Dias et al. (2001) \\
\hline $\mathrm{CH}_{3} \mathrm{OCH}_{2} \mathrm{OCH}_{3}+\mathrm{M} \rightleftharpoons \mathrm{CH}_{3} \mathrm{O}+\mathrm{CH}_{3} \mathrm{OCH}_{2}+\mathrm{M}$ & $2.51 \mathrm{E}+15$ & 0.0 & 76,800 & Dias et al. (2001) \\
\hline $\mathrm{CH}_{3} \mathrm{OCH}_{2} \mathrm{OCH}_{3}+\mathrm{H} \rightleftharpoons \mathrm{CH}_{3} \mathrm{OCH}_{2} \mathrm{OCH}_{2}+\mathrm{H}_{2}$ & $9.70 \mathrm{E}+13$ & 0.0 & 6210 & Dias et al. (2001) \\
\hline $\mathrm{CH}_{3} \mathrm{OCH}_{2} \mathrm{OCH}_{3}+\mathrm{H} \rightleftharpoons \mathrm{CH}_{3} \mathrm{OCHOCH}{ }_{3}+\mathrm{H}_{2}$ & $3.70 \mathrm{E}+12$ & 0.0 & 3240 & Dias et al. (2001) \\
\hline $\mathrm{CH}_{3} \mathrm{OCH}_{2} \mathrm{OCH}_{3}+\mathrm{OH} \rightleftharpoons \mathrm{CH}_{3} \mathrm{OCH}_{2} \mathrm{OCH}_{2}+\mathrm{H}_{2} \mathrm{O}$ & $9.10 \mathrm{E}+12$ & 0.0 & 986 & Dias et al. (2001) \\
\hline $\mathrm{CH}_{3} \mathrm{OCH}_{2} \mathrm{OCH}_{3}+\mathrm{OH} \rightleftharpoons \mathrm{CH}_{3} \mathrm{OCHOCH}_{3}+\mathrm{H}_{2} \mathrm{O}$ & $9.10 \mathrm{E}+12$ & 0.0 & 986 & Dias et al. (2001) \\
\hline $\mathrm{CH}_{3} \mathrm{OCH}_{2} \mathrm{OCH}_{3}+\mathrm{O} \rightleftharpoons \mathrm{CH}_{3} \mathrm{OCH}_{2} \mathrm{OCH}_{2}+\mathrm{OH}$ & $5.00 \mathrm{E}+13$ & 0.0 & 4570 & Dias et al. (2001) \\
\hline $\mathrm{CH}_{3} \mathrm{OCH}_{2} \mathrm{OCH}_{3}+\mathrm{O} \rightleftharpoons \mathrm{CH}_{3} \mathrm{OCHOCH}_{3}+\mathrm{OH}$ & $6.00 \mathrm{E}+13$ & 0.0 & 3970 & Dias et al. (2001) \\
\hline $\mathrm{CH}_{3} \mathrm{OCH}_{2} \mathrm{OCH}_{3}+\mathrm{CH}_{3} \rightleftharpoons \mathrm{CH}_{3} \mathrm{OCH}_{2} \mathrm{OCH}_{2}+\mathrm{CH}_{4}$ & $2.26 \mathrm{E}-05$ & 5.35 & 5810 & Dias et al. (2001) \\
\hline $\mathrm{CH}_{3} \mathrm{OCH}_{2} \mathrm{OCH}_{3}+\mathrm{CH}_{3} \rightleftharpoons \mathrm{CH}_{3} \mathrm{OCHOCH}_{3}+\mathrm{CH}_{4}$ & $5.00 \mathrm{E}+12$ & 0.0 & 9750 & Dias et al. (2001) \\
\hline $\mathrm{CH}_{3} \mathrm{OCH}_{2} \mathrm{OCH}_{2} \rightleftharpoons \mathrm{CH}_{2} \mathrm{O}+\mathrm{CH}_{3} \mathrm{OCH}_{2}$ & $1.00 \mathrm{E}+13$ & 0.0 & 32500 & Dias et al. (2001) \\
\hline $\mathrm{CH}_{3} \mathrm{OCH}_{2} \mathrm{O}+\mathrm{M} \rightleftharpoons \mathrm{CH}_{3} \mathrm{OCHO}+\mathrm{H}+\mathrm{M}$ & $7.00 \mathrm{E}+15$ & 0.0 & 22,800 & Dias et al. (2001) \\
\hline $\mathrm{CH}_{3} \mathrm{OCH}_{2} \rightleftharpoons \mathrm{CH}_{3}+\mathrm{CH}_{2} \mathrm{O}$ & $1.60 \mathrm{E}+13$ & 0.0 & 25,500 & Alzueta et al. (1999) \\
\hline $\mathrm{CH}_{3} \mathrm{OCHOCH} \mathrm{CH}_{3} \rightleftharpoons \mathrm{CH}_{3} \mathrm{OCHO}+\mathrm{CH}_{3}$ & $1.00 \mathrm{E}+13$ & 0.0 & 32,500 & Dias et al. (2001) \\
\hline $\mathrm{CH}_{3} \mathrm{OCHO}(+\mathrm{M}) \rightleftharpoons \mathrm{CH}_{3} \mathrm{OH}+\mathrm{CO}(+\mathrm{M})$ & $2.00 \mathrm{E}+13$ & 0.0 & 60,000 & Alzueta et al. (2013) \\
\hline $\mathrm{CH}_{3} \mathrm{OCHO}(+\mathrm{M}) \rightleftharpoons \mathrm{CH}_{4}+\mathrm{CO}_{2}(+\mathrm{M})$ & $1.50 \mathrm{E}+12$ & 0.0 & 59,700 & Alzueta et al. (2013) \\
\hline $\mathrm{CH}_{3} \mathrm{OCHO}(+\mathrm{M}) \rightleftharpoons \mathrm{CH}_{2} \mathrm{O}+\mathrm{CH}_{2} \mathrm{O}(+\mathrm{M})$ & $1.00 \mathrm{E}+12$ & 0.0 & 60,500 & Alzueta et al. (2013) \\
\hline
\end{tabular}

Note. $A$ in units of $\mathrm{cm}^{3}, \mathrm{~mol}, \mathrm{~s} ; E_{a}$ in $\mathrm{cal} / \mathrm{mol}$.

$$
\begin{gathered}
\mathrm{CH}_{3} \mathrm{OCHO}(+\mathrm{M}) \rightleftharpoons \mathrm{CH}_{4}+\mathrm{CO}_{2}(+\mathrm{M}) \\
\mathrm{CH}_{3} \mathrm{OCHO}(+\mathrm{M}) \rightleftharpoons \mathrm{CH}_{2} \mathrm{O}+\mathrm{CH}_{2} \mathrm{O}(+\mathrm{M})
\end{gathered}
$$

The kinetic parameters used for these reactions are reported in Table 2.

The methanol produced (r.1) is consumed giving mainly hydroxymethyl radicals 200 $\left(\mathrm{CH}_{2} \mathrm{OH}\right)$, which react mainly with molecular oxygen to give formaldehyde. It continues the $\mathrm{CH}_{2} \mathrm{O} \otimes \mathrm{HCO} \otimes \mathrm{CO} \otimes \mathrm{CO}_{2}$ reaction sequence. Methanol can also lead to the formation of $\mathrm{CH}_{4}$ through formaldehyde as intermediate.

These reaction routes can explain the pattern observed in Figures 2 and 3, in which the temperature for the maximum concentration of these compounds follows, increasing 205 in the following order: $\mathrm{MF}, \mathrm{CH}_{3} \mathrm{OH}$, and $\mathrm{CH}_{4}$.

The recombination of methyl radicals obtained through different routes, leads to the formation of ethane, which gives ethylene, and this one reacts to form acetylene as the final product. For this reason, the order, from the lowest to the highest temperature, in which the maximum concentration of these species appear, is: $\mathrm{C}_{2} \mathrm{H}_{6}, \mathrm{C}_{2} \mathrm{H}_{4}$, and $\mathrm{C}_{2} \mathrm{H}_{2}$.

A first-order sensitivity analysis for $\mathrm{CO}$ has been performed for all of the sets in Table 1. Figure 5 shows the results obtained. In the upper part of the figure, the sensitivity coefficients for reaction $\mathrm{CH}_{3} \mathrm{OCH}_{2} \mathrm{OCH}_{3}+\mathrm{CH}_{3} \rightleftharpoons \mathrm{CH}_{3} \mathrm{OCHOCH}_{3}+\mathrm{CH}_{4}$, which is clearly dominant, have been divided by two to clarify the representation and to better highlight the other reactions that are of comparatively minor importance. The results indicate that the conversion of DMM is mostly sensitive to the hydrogen abstraction by methyl radicals to obtain the secondary DMM radical $\left(\mathrm{CH}_{3} \mathrm{OCHOCH}_{3}\right)$ and also to the already mentioned DMM degradation reactions [(r.2) and (r.3)]. In the case of methyl formate, its conversion is sensitive to its degradation to methanol and CO (r.1). There are no huge discrepancies between the different $\lambda$ analyzed; only the 220 reactions where $\mathrm{OH}$ radicals participate present a bigger sensitivity under oxidizing conditions. 

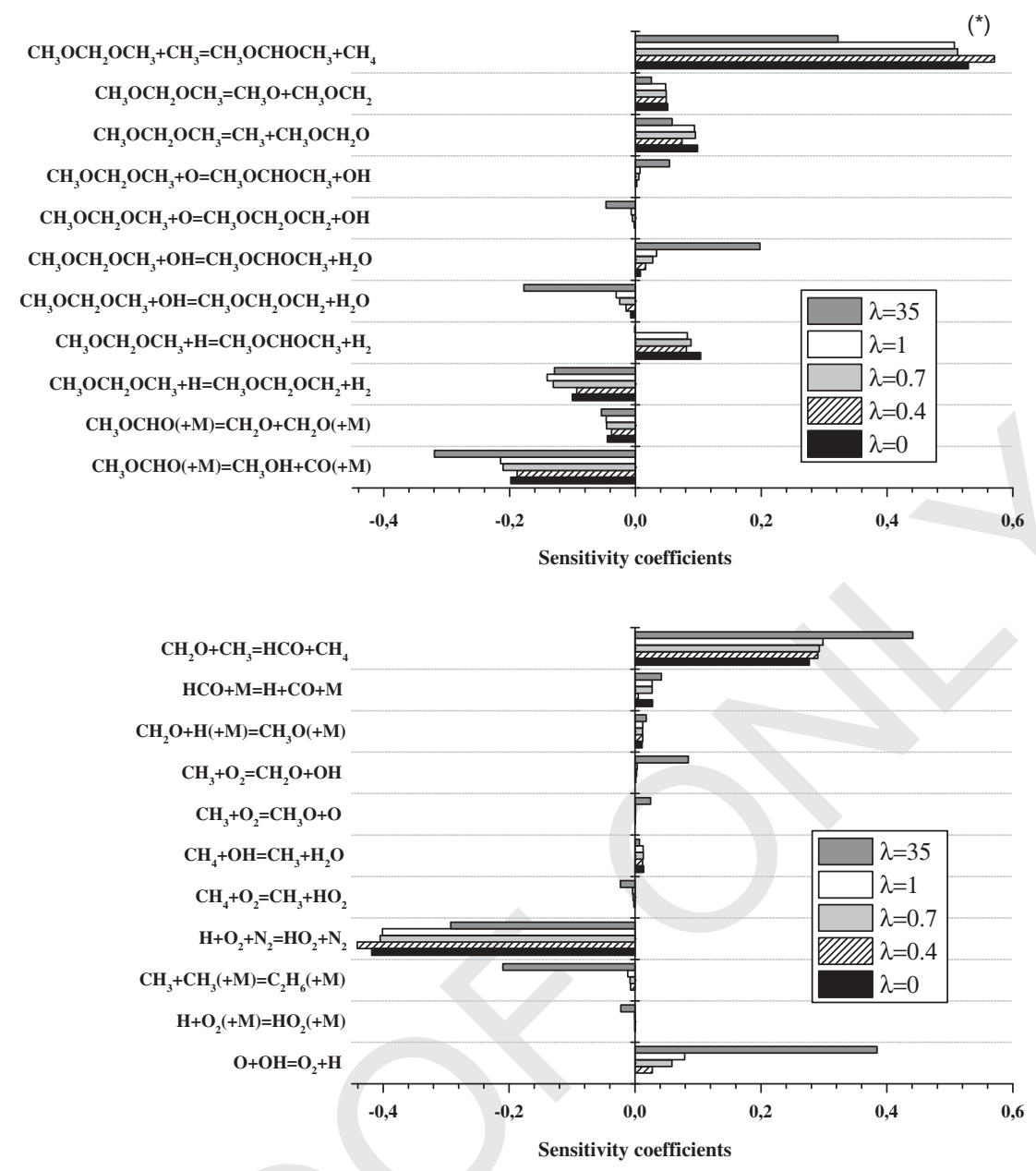

Figure 5. Sensitivity analysis for DMM for different air/fuel ratios. Upper part: sensitivity coefficients for DMM and MF reactions. Lower part: sensitivity coefficients for $\mathrm{CO}-\mathrm{C} 1$ reactions. $\left.{ }^{*}\right)$ The sensitivity coefficients have been divided by two.

\section{Conclusions}

The oxidation of DMM has been studied in a quartz flow reactor in the 573-1373 K temperature range, for different air/fuel ratios $(\lambda=0,0.4,0.7,1$, and 35) at atmospheric 225 pressure. The experimental data obtained have been interpreted in terms of a detailed chemical kinetic mechanism compiled from different works in the literature.

The oxygen concentration in the reactant mixture slightly influences the conversion of DMM; only for the oxidizing conditions, both experimental and theoretical results are shifted towards lower temperatures. However, in some reaction products, such as $\mathrm{CO}$ and $\mathrm{CO}_{2}$, certain effects can be observed. As the air excess ratio increases, the $\mathrm{CO}$ maximum concentration is shifted to lower temperatures and the concentration peak becomes narrower. $\mathrm{CO}_{2}$ formation is favored under stoichiometric and oxidizing conditions, where $\mathrm{CO}$ is completely oxidized to $\mathrm{CO}_{2}$. 
Methyl formate is an important intermediate formed during the DMM conversion. The 235 analysis of its main reaction pathways indicates that they are similar to those obtained in previous works about MF oxidation (Alzueta et al., 2013; Marrodán et al., 2014). Modeling calculations have been found to be very sensitive to the activation energy value for MF conversion to methanol and $\mathrm{CO}\left(\mathrm{CH}_{3} \mathrm{OCHO}(+\mathrm{M}) \rightleftharpoons \mathrm{CH}_{3} \mathrm{OH}+\mathrm{CO}(+\mathrm{M})\right)$.

Acetylene, considered as one of the main soot precursors, was only detected for pyrolysis and very reducing conditions.

Sensitivity and reaction rate analyses were performed to identify the main reactions involved in the DMM conversion. The results obtained indicate that the DMM conversion is initiated by degradation reactions, but hydrogen abstraction reactions also play an important role.

\section{Funding}

The authors express their gratitude to the Aragon Government and European Social Fund (GPT group), and to MINECO and FEDER (Project CTQ2012-34423) for financial support. Ms. L. Marrodán acknowledges the DGA (Diputación General de Aragón) for the predoctoral grant awarded.

\section{References}

Alzueta, M.U., Aranda, V., Monge, F., Millera, A., and Bilbao, R. 2013. Oxidation of methyl formate and its interaction with nitric oxide. Combust. Flame, 160, 853-860.

Alzueta, M.U., Bilbao, R., Millera, A., Oliva, M., and Ibañez, J.C. 1998. Interactions between nitric oxide and urea under flow reactor conditions. Energy Fuels, 12, 1001-1007.

Alzueta, M.U., Borruey, M., Callejas, A., Millera, A., and Bilbao, R. 2008. An experimental and modeling study of the oxidation of acetylene in a flow reactor. Combust. Flame, 152, 377-386.

Alzueta, M.U., and Hernández, J.M. 2002. Ethanol oxidation and its interaction with nitrogen oxide. Energy Fuels, 16, 166-171.

Alzueta, M.U., Muro, J., Bilbao, R., and Glarborg, P. 1999. Oxidation of dimethyl ether and its 260 interaction with nitrogen oxides. Isr. J. Chem., 39, 73-86.

Chao, M., Lin, T., Chao, H., Chang, F., and Chen, C. 2001. Effects of methanol-containing additive on emission characteristics from a heavy-duty diesel engine. Sci. Total Environ., 279, 167-179.

Daly, C.A., Simmie, J.M., Dagaut, P., and Cathonnet, M. 2001. Oxidation of dimethoxymethane in a jet-stirred reactor. Combust. Flame, 125, 1106-1117.

Dias, V., Lories, X., and Vandooren, J. 2010. Lean and rich premixed dimethoxymethane/oxygen/ argon flames: Experimental and modeling. Combust. Sci. Technol., 182, 350-364.

Dias, V., and Vandooren, J. 2011. Experimental and modeling studies of $\mathrm{C}_{2} \mathrm{H}_{4} / \mathrm{O}_{2} / \mathrm{Ar}, \mathrm{C}_{2} \mathrm{H}_{4} /$ methylal $/ \mathrm{O}_{2} / \mathrm{Ar}$ and $\mathrm{C}_{2} \mathrm{H}_{4} / \mathrm{O}_{2} / \mathrm{Ar}$ rich flames and the effect of oxygenated additives. Combust. Flame, 158, 848-859.

Dooley, S., Burke, M.P., Chaos, M., Stein, Y., Dryer, F.L., Zhukov, V.P., Finch, O., Simmie, J.M., and Curran, H.J. 2010. Methyl formate oxidation: Speciation data, laminar burning velocities, ignition delay times, and a validated chemical kinetic model. Int. J. Chem. Kinet., 42, 527-549.

Glarborg, P., Alzueta, M.U., Dam-Johansen, K., and Miller, J.A. 1998. Kinetic modeling of hydrocarbon/nitric oxide interactions in a flow reactor. Combust. Flame, 115, 1-27.

Glarborg, P., Alzueta, M.U., Kjærgaard, K., and Dam-Johansen, K. 2003. Oxidation of formaldehyde and its interaction with nitric oxide in a flow reactor. Combust. Flame, 132, 629-638.

He, B., Shuai, S., Wang, J., and He, H. 2003. The effect of ethanol blended diesel fuels on emissions from a diesel engine. Atmos. Environ., 37, 4965-4971. 
Kee, R.J., Rupley, F.M., and Miller, J.A. 1991. CHEMKIN II: A FORTRAN chemical kinetics package for the analysis of gas-phase chemical kinetics. Report SAND87-8215. Sandia National Laboratories, Albuquerque, NM.

Kristensen, P.G., Glarborg, P., and Dam-Johansen, K. 1996. Nitrogen chemistry during burnout in fuel-staged combustion. Combust. Flame, 107, 211-222.

Lutz, A.E., Kee, R.J., and Miller, J.A. 1988. SENKIN: A FORTRAN program for predicting homogeneous gas phase kinetics with sensitivity analysis. Report SAND87-8248. Sandia National Laboratories, Livermore, CA.

Marrodán, L., Millera, A., Bilbao, R., and Alzueta, M.U. 2014. High-pressure study of methyl formate and its interaction with NO. Energy Fuels, 28, 6107-6115.

Molera, M.J., Domínguez, J.A., and Santiuste, J.M. 1977. Gas-phase oxidation of dimethoxy methane- ${ }^{14}$ C. An. Quim., 73, 467-471.

Ribeiro, N.M., Pinto, A.C., Quintella, C.M., da Rocha, G.O., Teixeira, L.S.G., Guarieiro, L.L.N., Rangel, M.C., Veloso, M.C.C., Rezende, M.J.C., da Cruz, R.S., Oliveira, A.M., Torres, E.A., and de Andrade, J.B. 2007. The role of additives for diesel and diesel blended (ethanol or biodiesel) fuels: A review. Energy Fuels, 21, 2433-2445.

Sinha, A., and Thomson, M.J. 2004. The chemical structures of opposed flow diffusion flames of C3 oxygenated hydrocarbons (isopropanol, dimethoxymethane, and dimethyl carbonate) and their mixtures. Combust. Flame, 136, 548-556.

Skjøth-Rasmussen, M.S., Glarborg, P., Østberg, M., Johannessen, J.T., Livbjerg, H., Jensen, A.D., and Christensen, T.S. 2004. Formation of polycyclic aromatic hydrocarbons and soot in fuel-rich 300 oxidation of methane in a laminar flow reactor. Combust. Flame, 136, 91-128.

Song, K.H., and Litzinger, T.A. 2006. Effects of dimethoxymethane blending into diesel fuel on soot in an optically accessible DI diesel engine. Combust. Sci. Technol., 178, 2249-2280.

Ying, W., Genbao, L., Wei, Z., and Longbao, Z. 2008. Study on the application of DME/diesel blends in a diesel engine. Fuel Process. Technol., 89, 1272-1280.

Zhang, C., Li, P., Li, Y., He, J., and Li, X. 2014. Shock-tube study of dimethoxymethane ignition at high temperatures. Energy Fuels, 28, 4603-4610. 